\title{
MANAJEMEN PEMBANGUNAN PABRIK PADI
}

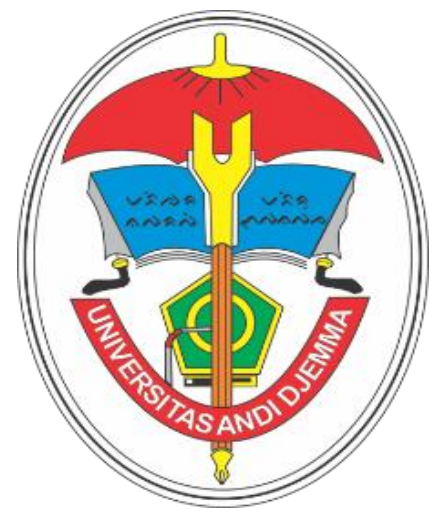

DISUSUN OLEH :

NAMA : TRI AGUNG MULIYA

NIM : 18.023.22.201.036

PEMBIMBING :

AMIRUDDIN AKBAR FISU, S.T., M.T.

PROGRAM STUDI SIPIL

FAKULTAS TEKNIK

UNIVERSITAS ANDI DJEMMA

2021 


\section{BAB I}

\section{PENDAHULUAN}

\section{A. Latar Belakang}

Indonesia adalah negara agraris yang sebagian besar penduduknya terdiri dari petani sehingga sektor pertanian memegang peranan penting. Sektor pertanian sebagai sumber kehidupan bagi sebagian besar penduduk terutama bagi mereka yang memiliki mata pencaharian utama sebagai petani. Selain itu, sektor pertanian berperan penting dalam menyediakan bahan pangan bagi seluruh masyarakat maupun menyediakan bahan baku bagi industri, dan untuk perdagangan ekspor (Suparta, 2010).

Salah satu pilar ekonomi negara, sektor pertanian diharapkan dapat meningkatkan pendapatan terutama dari penduduk pedesaan yang masih di bawah garis kemiskinan. Padi merupakan tanaman pangan utama di Indonesia karena sebagian besar penduduk Indonesia mengkonsumsi beras sebagai sumber karbohidrat. Pengembangan usaha disektor pertanian dan industri perlu didorong dan dibina menjadi suatu usaha yang berkembang, sehingga mampu mandiri dan dapat meningkatkan pendapatan masyarakat.

Penggilingan padi memiliki peran yang sangat penting dalam sistem agribisnis padi/perberasan di Indonesia. Peranan ini tercermin dari besarny jumlah penggilingan padi dan sebarannya yang hampir merata di seluruh daerah sentra produksi padi di Indonesia. Penggilingan padi merupakan pusat pertemuan antara produksi, pasca panen, pengolahan dan pemasaran gabah/beras sehingga merupakan mata rantai penting dalam suplai beras nasional yang dituntut untuk dapat memberikan kontribusi dalam penyediaan beras, baik dari segi kuantitas maupun kualitas untuk mendukung ketahanan pangan nasional.

Industri penggilingan padi di Indonesia masih ada yang menggunakan teknologi yang sederhana. Sebagai akibatnya, beras yang dihasilkan kualitas dan remendemen beras yang rendah.

Secara umum mutu beras dapat dikelompokkan ke dalam 4 kategori, yaitu mutu giling, mutu rasa dan mutu tunak, mutu gizi, dan standar spesifik untuk penampakan dan kemurnian biji (misalnya besar, bentuk dan kebeningan beras). Mutu beras giling dikatakan baik jika hasil proses penggilingan diperoleh beras kepala yang banyak dengan beras patah minimal. Mutu giling ini juga ditentukan dengan banyaknya beras putih atau rendemen yang dihasilkan. Mutu giling ini sangat erat kaitannya dengan nilai ekonomis dari beras. Mutu giling mencakup berbagai ciri, yaitu rendemen 
beras giling, rendemen beras kepala, persentase beras pecah, dan derajat sosoh beras. Sebagian besar beras yang beredar di beberapa daerah di Indonesia memiliki derajat sosoh $80 \%$ atau lebih dan persentase beras kepala lebih besar dari $75 \%$ dan mengandung butir patah kurang dari $30 \%$ Salah satu kendala dalam produksi beras adalah banyaknya beras pecah sewaktu digiling. Hal ini dapat menyebabkan mutu beras menurun (Allidawati dan Kustianto, 1989).

Namun usaha penggilingan padi ini tidak lah dapat dioprasikan karena ada beberapa alat yang belum ada sama sekali, dimana kelompok tunas harapan meminta di walikota melalui dinas pertanian kota palopo untuk mensegerakan permohonan tersebut. Sehingga penggilingan padi dapat beroperasi pada saat musim panen di sekitar wilayah kelurahan jaya, kecamatan telluwanua.

Biaya yang dikeluarkan dalam pelaksanaan usaha penggilingan padi bukanlah sedikit atau tidak murah, karena penggilingan padi itu sendiri menggunakan alat yang mahal ditambah lagi dengan biaya tenaga kerja, biaya penyusutan, biaya bahan bakar serta oli dan biaya-biaya lainnya.

B. Rumusan Masalah

Berdasarkan latar belakang masalah yang telah di uraikan diatas maka dapat dirumuskan pokok permasalahan, yaitu "Apakah kendala pada mesin pabrik sampai saat ini belum beroperasional”

C. Tujuan Penelitian

Untuk mengetahui kendala pada mesin pabrik sampai saat ini belum beroperasian

\section{Batasan Penelitian}

Batasan masalah dalam penelitian ini adalah kegiatan yang dilakukan pabrik penggilingan padi Tri Muliya yang berlokasi di kelurahan jaya kecamatan telluwanua, Kota Palopo. 


\section{BAB II}

\section{LANDASAN TEORI}

Penggilingan padi merupakan industri padi tertua dan tergolong paling besar di Indonesia, yang mampu menyerap lebih dari sepuluh juta tenaga kerja, menangani lebih dari empat puluh juta ton gabah menjadi beras giling per tahun. Penggilingan padi merupakan titik sentral agroindustri padi, karena disinilah diperoleh produk utama berupa beras dan bahan baku untuk pengolahan lanjutan produk pangan dan industri. (Thahir, 2008) Penanganan pascapanen adalah tindakan yang dilakukan atau disiapkan agar hasil pertanian siap dan aman digunakan oleh konsumen atau dapat diolah lebih lanjut melalui kegiatan produksi. Penanganan pascapanen padi meliputi semua kegiatan perlakuan dan pengolahan yang meliputi proses pemotongan, perontokan, pengangkutan, perawatan, pengeringan, penyimpanan, penggilingan, penyosohan, pengemasan, dan pengolahan (Setyono, 1994).

Secara umum, mesin-mesin yang digunakan dalam usaha industri jasa penggilingan padi adalah mesin pemecah kulit/sekam, (huller atau husker), mesin pemisah gabah dan beras pecah kulit (brown rice separator), mesin penyosoh atau mesin pemutih (polisher), mesin pengayak bertingkat (sifter), mesin atau alat bantu pengemasan (timbangan dan penjahit karung). Bila ditinjau dari kapasitasnya, mesinmesin penggiling padi dapat dibagi menjadi dua jenis yaitu rice millingunit (RMU) dan rice milling plant (RMP). Perbedaan yang mendasar antara keduanya adalah pada ukuran, kapasitas dan aliran bahan dalam proses penggilingan yang dilakukan. Penggilingan padi yang lengkap kadangkala dilengkapi dengan pembersih gabah sebelum masuk mesin pemecah kulit, dan pengumpul dedak sebagai hasil sampingan dari proses penyosohan. Gabah yang ditumbuk dengan menggunakan alu dan lesung memerlukan lebih banyak tenaga kerja dan waktu. Butiran beras yang dihasilkan juga kurang baik karena banyak butiran yang pecah sehingga hanya cocok untuk konsumsi sendiri. Sebaliknya dengan mesin penggiling, tenaga dan waktu yang diperlukan lebih sedikit dan hasilnya pun lebih baik (Andoko, 2006). Di Indonesia, usaha penggilingan gabah dikelompokkan berdasarkan kapasitas penggilingan yang meliputi penggilingan sederhana (PS), penggilingan kecil (PK), penggilingan besar atau terpadu (PB). Jenis usaha penggilingan gabah yang termasuk dalam penggilingan sederhana dan penggilingan kecil merupakan yang paling banyak ditemui di pedesaan pada umumnya. Secara umum, penggilingan sederhana dan penggilingan kecil 
memiliki karakteristik secara umum menghasilkan beras dengan mutu rendah, skala ekonominya kecil dan jangkauan pemasarannya lokal (Hasbullah, 2007).

Penggilingan padi yang lengkap kadangkala dilengkapi dengan pembersih gabah sebelum masuk mesin pemecah kulit, dan pengumpul dedak sebagai hasil sampingan dari proses penyosohan.

Beberapa proses yang terlibat dalam rice milling plant yaitu :

1. Sortasi 1 Pemisahan kotoran dari padi hasil panen di sawah dilakukan karena masih banyak kotoran yang terbawa seperti jerami, daun, batang, bahkan benda lain seperti batu dan pasir.. Alat yang digunakan dalam sortasi 1 adalah paddy cleaner yang berfungsi untuk memisahkan kotoran / benda asing yang bercampur dalam gabah seperti jerami, jerami halus dan debu.

2. Pengeringan Kadar air padi hasil panen sangat bervariasi antara 25-30\%. Pada musim hujan, kadar air padi berkisar antara 25-30\%, sedangkan pada musim kemarau kadar air padi berkisar antara 21-25\%. Pengeringan dilakukan untuk mengurangi kadar air sampai sekitar 14\% sehingga memudahkan dan mengurangi kerusakan dalam penyosohan dan proses selanjutnya. Kadar air yang terlalu tinggi menyulitkan pengupasan kulit dan menyebabkan kerusakan (pecah atau hancur) karena tekstur yang lunak. Alat yang digunakan yaitu dryer.

3. Sortasi 2 (penggilingan) Penggilingan gabah dimulai dengan proses pemecahan dan pengupasan kulit/sekam, dilanjutkan penyosohan beras pecah kulit (BPK) dan diakhiri dengan pemutuan (grading), sebelum dikemas dan dijual. Mesin pemecah kulit/sekam gabah kering giling berfungsi untuk memecahkan dan melepaskan kulit gabah. Gabah yang diumpankan ke dalam mesin pemecah kulit biasanya tidak seluruhnya terkupas. Besar kecilnya persentase gabah tidak terkupas ini tergantung pada penyetelan mesin. Bagian yang tidak terkupas tersebut harus dipisahkan dari beras pecah kulit untuk diumpankan kembali kedalam mesin pemecah kulit. Pemisahan ini dilakukan dengan menggunakan mesin pemisah gabah dari beras pecah kulit, yang dapat menyatu atau terpisah dengan mesin pemecah kulit.

Penyosohan adalah pengupasan kulit padi yang merupakan tahapan paling penting dari keseluruhan proses. Penglupasan kulit adalah transformasi padi menjadi beras yang secara prinsip sudah dapat dimasak untuk dimakan. Proses selanjutnya hanyalah penyempurnaan dari penyosohan dan untuk meningkatkan kebersihan. Mesin yang digunakan pada proses ini disebut polisher. Penyosohan dilakukan untuk membuang lapisan bekatul dari butiran beras. Di samping membuang lapisan bekatul, pada proses ini juga dibuang bagian lembaga dari butiran beras. Setelah itu, padi 
mengalami pengayakan yang terakhir pada paddy separator yang berfungsi memisahkan gabah yang bercampur dengan beras pecah kulit.

Penggilingan adalah proses pemisahan sekam dan kulit luar kariopsis dari biji padi agar diperoleh beras yang dapat dikonsumsi. Penggilingan beras berfungsi untuk menghilangkan sekam dari bijinya dan lapisan aleuron, sebagian maupun seluruhnya agar menghasilkan beras yang putih serta beras pecah sekecil mungkin. Setelah gabah dikupas kulitnya dengan menggunakan alat pecah kulit, kemudian gabah tersebut dimasukkan ke dalam alat penyosoh untuk membuang lapisan aleuron yang menempel pada beras. Selama penyosohan terjadi, penekanan terhadap butir beras sehingga terjadi butir patah. Menir merupakan kelanjutan dari butir patah menjadi bentuk yang lebih kecil daripada butir patah.

Diagram Alir Proses Penggilingan Padi Menjadi Beras Penggilingan padi menjadi beras melewati beberapa tahapan, yaitu :

1. Perontokan Padi Perontokan padi dilakukan dengan alat rontogan, bertujuan untuk melepaskan gabah dari tangkai nya dan juga memisahkan butiran padinya. Sehingga nantinya akan didapatkan gabah kotor. Dan hasil yang tidak dipakai berupa merang.

2. Sortasi Sortasi ini bertujuan untuk memisahkan bagian-bagian yang tidak terpakai pada proses pengolahan beras yaitu berupa kotoran, kerikil, dan batu-batuan atau benda-benda asing lainnya. Sehingga hasil yang didapatkan pada proses sortasi ini berupa gabah bersih, atau keseluruhan hanya berupa gabah saja tanpa ada kerikil ataupun batuan lainnya.

3. Penggilingan (Rice Milling) Penggilingan adalah proses pemisahan sekam dan kulit luar kariopsis dari biji padi agar diperoleh beras yang dapat dikonsumsi. Terdapat berbagai jenis teknologi/alat yaitu penumbukan (lesung/kincir air), penggilingan tipe Engelberg,Rice Milling Unit (RMU) dan penggilingan padi besar. Hasil yang dihasilkan dari proses penggilingan adalah beras pecah kulit.

4. Penyosohan Penyosohan berfungsi untuk memisahkan beras dengan dedak. Pada proses ini digunakan mesin penyosoh (rice polisher), mesin I (penyosohan I), mesin II (penyosohan II) yang terdiri dari batu penyosoh (batu amaril) dan lempengan karet. Karena ada gesekan antara beras dengan batu, lempengan karet, dan antara sesam beras maka beras akan tesosoh; bahan yang digunakan adalah beras pecah kulit sehingga akhrinya akan dihasilkan beras sosoh, dedak (didapat dari mesin sosoh I), bekatul (mesin sosoh II). Bekatul akan langsung dipisahkan dengan aspirator.

5. Grading Proses grading bertujuan untuk memisah-misahkan beras kepala, beras patah dan menir. Bahan yang digunakan adalah beras sosoh dan alat yang digunakan adalah ayakan beras (honkwl beras); dan akan menghasilkan beras kepala, beras patah dan menir. 
Mesin penggiling padi Bulog Purbalingga dapat dikatakan memadai karena terdiri dari komponen mesin, yaitu :

1. Mesin Pembersih Gabah (Paddy Cleaner) Berfungsi unuk memisahkan kotoran/ benda asing yang bercampur di dalam gabah. Setelah melalui mesin ini akan mengalami penyusutan berat yang besarnya sangat tergantung pada jumlah kotorannya

2. Mesin Pecah Kulit (Paddy Husker) Berfugsi untuk mengupas kulit gabah. Pada mesin pecah kulit yang berkualitas baik, ratio pengupasan ditentukan antara 85-90\% gabah sudah terkupas dan 10-15\% gabah belum terkupas. Faktor lain yang dapat mempengaruhi rasio pengupasan adalah kualitas roll karet yang digunakan.

3. Separator Berfungsi untuk memisahkan gabah yang bercampur dengan beras pecah kulit. Dengan adanya separator maka daya tahan komponen utama pada mesin pemutih menjadi awet, karena proses pengelupasan kulit ari selama masih di dalam ruang pemutihan, murni, hanya berdasarkan pergesekan antar beras pecah kulit.

4. Mesin Pemisah Batu (De-Stoner) Berungsi untuk memisahkan batu yang bercampur dengan beras pecah kulit.

5. Mesin Pemutih Batu (Abrassive) Berfungsi sebagai pra-poles atau untuk mengawali proses pengelupasan lapisan kulit ari beras yang menutup biji beras dari setiap pemutihan yang lebih dari satu pass. Dengan memakai mesin pemutih batu, disamping tingkat butir patah dapat ditekan pada presentase yang terkecil juga tingkat derajat sosoh diatur sejak dari fase ini. Sehingga untuk fase selanjutnya beban gaya gesek beras menjadi berkurang.

6. Mesin Pemutih Besi (Friction) Berfungsi sebagai pemutih akhir dari rangkaian proses pemutihan beras 2 atau 3 kali proses/ pass pemutihan/ penyosohan.

7. Mesin Pengkilap (Rice Refiner) Berfungsi untuk mencuci permukaan biji beras, dimana umumnya masih terdapat katul yang menempel. Beras yang dihasilkan oleh mesin ini selain secara visual tampak kilap (benih kaca) dan bila disimpan dapat bertahan lama.

8. Mesin Pemecah Menir (Rice Sifter) Berfungsi untuk memisahkan kandungan menir yang bercampur didalam beras kepala maupun beras patah.

9. Mesin Pemisah Antara Beras Kepala dan Beras Patah (Rice Grader)

Berfungsi untuk memisahkan beras kepala dari percampuran beras patah.

Keberadaan mesin ini terutama diperuntukkan untuk membuat beras berkulitas ekspor/ super.

Namun secara umum, mesin-mesin yang digunakan dalam industry penggilingan padi dikelompokkan sebagai berikut: 
a) Mesin pemecah kulit/ sekam atau pengupas kulit/ sekam gabah kering giling (huskeratau huller)

b) Mesin pecah gabah atau beras pecah kulit (brown rice separator)

c) Mesin penyosoh atau mesin pemutih (polisher)

d) Mesin pengayak bertingkat (sifter)

e) Mesin atau alat bantu pengemasan

\section{BAB III METODE PENELITIAN}

\subsection{Lokasi dan Waktu Penelitian}

Penelitian ini dilaksanakan di Kelurahan Jaya, Kecamatan Telluwanua, Kota Palopo, Provinsi Sulawesi Selatan. Pemilihan lokasi ini secara sengaja (purposive) dengan pertimbangan di wilayah ini yang luas hamparan persawahan. Penelitian ini dilakukan pada Bulan Juli 2021.

3.2 Pendekatan Penelitian

Penelitian ini dilakukan dengan metode multiple case study. Melalui metode multiple case study diharapkan peneliti bisa menggambarkan secara rinci dan dapat membandingkan masingmasing objek penelitian. Pada metode ini hasil yang diperoleh hanya menggambarkan usaha yang menjadi objek penelitian atau dengan arti lain mengalami idle capacity. Hal ini terjadi karena beberapa hal, seperti terbatasnya jumlah pelanggan yang menggunakan jasa usaha penggilingan padi. Selain itu, pelanggan yang menggunakan jasa penggilingan tersebut adalah skala jumlah banyak.

\subsection{Metode Survei}


Jenis dan sumber data yang digunakan dalam penelititian ini adalah data yang diperoleh langsung dari lokasi penelitian berupa observasi maupun wawancara langsung 


\section{DAFTAR PUSTAKA}

[1] Nurhijrah, N., \& Fisu, A. A. (2020). Place Memory Masyarakat pada Bangunan Cagar Budaya di Kota Palopo. RUAS (Review of Urbanism and Architectural Studies), 17(2), 63-70.

[2] Ahmad, A., Fisu, A. A., \& Didiharyono, D. (2019). Analisis Potensi Ekosistem Mangrove Sebagai Pengembangan Objek Wisata (Studi Kasus: Kabupaten Wakatobi). Prosiding, 4(1).

[3] Marzaman, L. U., Hafid, Z. A., Fisu, A. A., \& Nurhijrah, N. (2019). PLACE MAKING WORKSHOP BATUPASI SUB DISTRICT PALOPO CITY. To Maega: Jurnal Pengabdian Masyarakat, 2(1), 1-8.

[4] Hidayat, A., \& Fisu, A. A. (2020). Konsep Arsitektur Panti Rehabilitasi Ketergantungan Narkotika \& Psikotropika Di Makassar, Pendekatan Arsitektur Postmodern Historiscm. PENA TEKNIK: Jurnal IImiah IImu-IImu Teknik, 5(1), 31-43.

[5] Sulaiman, L., \& Fisu, A. A. (2020). Pengaruh Campuran Terhadap Kuat Tekan Beton Agregat Recycle. Rekayasa Sipil, 14(1), 35-42.

[6] Winarno. 2004. GMP dalam Industry Penggilingan Padi

[7] Sulardjo, 2014. Penanganan Pascapanen Padi

[8] Andoko, 2006 Mesin penggilingan

[9] Sugiyono, 2010. Metode Penelitian

[10] Fisu, A. A. (2019). Merawat Nilai Membangun Kota.

[11] Marzaman, L. U., \& Fisu, A. A. (2020). Hunian Vertikal Kontainer Buruh Pt Kima Dengan Konsep Arsitektur Humanis. PENA TEKNIK: Jurnal IImiah IImu-IImu Teknik, 5(2), 91-103.

[12] Marzaman, L. U., Hafid, Z., \& FISU, A. A. MERAJUT CERITA DI KOTA TUA (REVITALISASI KAWASAN EX PASAR LAMA PALOPO).

[13] Fisu, A. A., \& Didiharyono, D. (2020, April). Economic \& Financial Feasibility Analysis of Tarakan Fishery Industrial Estate Masterplan. In IOP Conference Series: Earth and Environmental Science (Vol. 469, No. 1, p. 012002). IOP Publishing

[14] Fisu, A. A. (2019). 17 Tahun Kota Palopo: Kota, Manusia dan Para Penggerak.

[15] Nurhijrah, N., Fisu, A. A., Marzaman, L. U., \& Hafid, Z. KONSEP PENATAAN KAWASAN LALEBBATA SEBAGAI KAWASAN HERITAGE DI KOTA PALOPO. Jurnal Arsitektur ZONASI, 4(1).

[16] Fisu, A. A. (2018). ANALISIS LOKASI PADA PERENCANAAN TERMINAL TOPOYO MAMUJU TENGAH. PENA TEKNIK: Jurnal IImiah IImu-IImu Teknik, 3(1), 1-12.

[17] FISU, A. A. STUDI AWAL LOKASI RENCANA PELABUHAN DI TELUK PRIGI KABUPATEN TRENGGALEK. 
